J O U R N A O F French and Francophone Philosophy
REV UE DE LA

philosophie française et de langue française

\title{
Shorelines
}

\section{In Memory of Édouard Glissant}

\author{
John E. Drabinski
}

Journal of French and Francophone Philosophy - Revue de la philosophie française et de langue française, Vol XIX, No 1 (2011) pp 1-10

\author{
Vol XIX, No 1 (2011) \\ ISSN 1936-6280 (print) \\ ISSN 2155-1162 (online) \\ DOI 10.5195/jffp.2011.473 \\ http: / / www.jffp.org
}

\section{(cc) EY-No-No}

This work is licensed under a Creative Commons Attribution-Noncommercial-No Derivative Works 3.0 United States License.

\section{ULIS D-Sont}

This journal is operated by the University Library System of the University of Pittsburgh as part of its D-Scribe Digital Publishing Program, and is co-sponsored by the University of Pittsburgh Press 


\title{
Shorelines
}

\section{In Memory of Édouard Glissant}

\author{
John E. Drabinski \\ Amherst College
}

Édouard Glissant passed away on 4 February 2011 at the age of 82. A few words of memory.

As a person and thinker, Glissant lived through, then reflected with meditative patience and profundity upon some of the most critical years in the black Atlantic: the aesthetics and politics of anti-colonial struggle, the civil rights movement in the United States, postcolonial cultural anxiety and explosion, the vicissitudes of an emerging cultural globalism, and all of the accompanying intellectual movements from surrealism to negritude to existentialism to those varieties of high modernism and postmodernism for which Glissant himself is such a generative, founding resource. His life bears witness to those years, events, and movements with a poet's word and a philosopher's eye. And so Glissant, like all important thinkers, leaves for us an enormous gift - in his case, a new, enigmatic vocabulary of and for the Americas.

Glissant offers us in his life, and also now with his passing, an astonishing set of reflections in poetry, theater, novels, cultural criticism, and philosophy, all of which rewrite the histoire of the Americas and obligate us to think otherwise. The Americas require a very different sense of knowing and being, and so a very different sense of poetics and aesthetics. The New World is mixed and mixing, an inheritance of violence, survival, reinvention, and invention. In rewriting the Americas, Glissant also rewrites the identity of Europe by asking if the project (and not place) called "the West" can genuinely be thought outside the entanglements of empire. Perhaps so much involvement for so long and with such dependency alters the meaning of the identity of a nation and culturally constructed "region." No, not perhaps. It must be so. Five centuries of entanglement cannot be disentangled from identity. Europe lived both economically and intellectually from a machine of exploitation and violence. Can we imagine European wealth without the slave trade and colonial exploitations? Have we begun to fathom the 
significance of the fact that all aspects of European culture intervened (with very few critiques) to justify slavery and colonial subjugation? Yet, questions of European national and regional identity typically excise entanglement and imagine a bordered place to have a unique, centralized meaning. What colonial fantasies underpin such an imagined purity and single-rootedness? There is no meaning to "Europe" without the violence of conquest, subjugation, and domination, just as Caribbean identity (which has always wrestled with entangled cultural forces as an analytical starting point) is entwined with the complicated legacy of colonial power. Glissant's challenge to us, no matter our location or cultural milieu, is to think, live, and create in this incredibly complicated, entangled, and intertwined intellectual space. A poetics of the mangrove, we might say.

For these reasons, one cannot write without Glissant. Or at least one should not. To write without Glissant in mind is to miss, then eclipse some of the most overwhelming and system-overturning conceptual critiques to be found on the contemporary scene. He has fundamentally transformed how we understand history and memory in the New World (and, by implication, the Old World and the global south more generally. The world is tout-monde.). Glissant's account of New World history and memory requires so much of us as thinkers. Space and time curve and fragment, rather than loop and fold. Continuity is broken and the imagination, working with fragments, becomes a kind of intellectual djobber. Nomads and rhizomes replace homes and roots, putting a decisive and compelling twist on Gilles Deleuze's and Félix Guattari's revolutionary reinvention of philosophy. In the wake of curves and fragments, in the space of nomadic movement and rhizomatic contact with place, the historical experience of the New World produces (and is produced by) a creolized and archipelagic space. This space is defined by its creative chaos and fractal character, rather than by fixity and continuity. Creolized space emerges, in Glissant's work, after so much violent and traumatic history. Memory of pain, he argues, is not just remembrance of the dead and their unspeakable suffering, but also the memory of a great re-making of the world in the strange temporality of a globalized and globalizing geography. The Caribbean, after all, is that first geography - writing the geos - of globalized culture, language, and meaning - a strange and terrifying experiment in devastation, violence, and creation that has produced a creolized space. A mixed space of becoming, exceeding so many of the philosophical categories one finds in Western philosophy.

These are, in the most general terms, Glissant's great and foundational insights. From these insights, a wholly enigmatic and compelling theoretical vocabulary emerges. And these are the insights to which we who work in his wake have to answer and must continue, not only out of a reverence for a great thinker (though that would be plenty sufficient), but also and firstly out of respect for the pain and beauty of history and memory in the New World context. 
How did Glissant come to conceive this productive chaos?

Glissant's life and work are in many ways just so singular, and yet, from the beginning, it engaged all of those critical issues and moments of anti-colonial struggle and decolonization. He was born in Martinique in 1928, just three years after Frantz Fanon and two years before Derek Walcott, then moved to Paris in 1946 to study philosophy, history, and ethnology. We see all of that and more in his work - so much theory, so much reflection on the meaning of history and historical experience, so much serious study of culture. While in Paris, Glissant famously got involved in radical anti-colonial politics with Paul Niger and others, which led Charles de Gaulle to forbid Glissant's return to Martinique and then dissolve their group Front des Antilles-Guyane pour l'autonomie (FAGA). Glissant returned to Martinique after the ban was lifted in 1965 and founded the Institut Martiniquais d'Études in 1967, then the journal Acoma a few years later. In the 1980s and 1990s, Glissant relocated to Paris (working on the UNESCO Newsletter), then later took a position at Louisiana State University, then eventually settled at City University of New York in 1995. His work in the first decade of the twenty-first century included theoretical interventions in poetics (La cohée du Lamentin, Une nouvelle région du monde, others), philosophy (Philosophie de la relation), politics (a series of pamphlets co-authored with Patrick Chamoiseau, the masterwork Mémoires des esclavages, which featured an avant-propos by Dominique de Villepin), and the utterly enigmatic, adventurous collection of what Glissant calls la poésie $d u$ tout-monde entitled La Terre, le feu, l'eau, et les vents - a collection that includes selections from Socrates, Shakespeare, Montaigne, Perse, Muhammad Ali, Neruda, Ibn Arabi, Gandhi, and so many more. This last collection, published in 2010, tells so much of Glissant's intellectual story and is a fitting way for him to leave our world. La Terre, le feu, l'eau, et les vents brings the playful, erudite, and global character of Glissant's poetics to the page, creating for the reader a swirling, chaotic play of words that testify, in writing and voice, to a genuinely global sense of vernacular poetic expression. There is no center, only poetry. As well, in his last years, the questions of poetics and thinking through what he called simply tout-monde turned increasingly more toward direct political work. Pamphlets on nationalism, memory, and even Barack Obama's election give political bite to Glissant's poetics, just as his writing on the memory of the slave trade in Mémoires des esclavages and its accompanying cultural projects puts traumatic remembrance back in the center of France and French history and identity.

Poetry, theater, novels, philosophy, aesthetics, politics, and provocative editorial work. Glissant leaves us with much to read, much to consider. So, I want to say a bit more about those ideas as a form of memorial. First, a short personal note.

I read Glissant for the first time in a seminar with David Carroll at The School of Criticism and Theory at Cornell University. The summer seminar 
was dedicated to questions of trauma, representation, and the Shoah, with special attention to theories of history and historiography. We covered some familiar, even at this point canonical ground, theorizing the unrepresentable and trauma through Jean-François Lyotard, Maurice Blanchot and others, put those ideas in critical relation to Hegel's philosophy of history, and then brought the discussion to bear on a viewing of Claude Lanzmann's Shoah. This was my interest going into the summer session of SCT: how can we think about the violent past? And what does it mean to go on, even when the future seems impossible? The European theory on these questions is both wide and deep and we read, discussed, and debated an enormous cluster of ideas. But we ended with Glissant. How strange, given the European emphasis of the seminar. Why travel the Atlantic in thinking this trauma of Europe, I wondered? Well, it was quite simple: ending with Glissant was Carroll's way of opening questions of trauma outside the European context, thereby complicating (if not overturning) all of the conceptual, philosophical presuppositions one finds operating in that context. In its own way, a brilliant critical subversion of our very casual universalizing discourse. I certainly felt instructed, in part by Carroll's choice, but much more by Glissant's meditative and poetic prose. We read Poetics of Relation and, due to predictable time constraints (it is so hard to stick to a syllabus!), we dealt with it only very briefly, mostly gesturing toward what I still think is Glissant's most important and enigmatic contribution to contemporary trauma studies: the obstinacy of the future.

I wore out my copy and bought another from the Cornell University bookstore for fresh marginal comments. I knew immediately that the justover two hundred pages of reflection on Caribbeanness and the Americas would change my intellectual life and trajectory for the foreseeable future, and one always needs a fresh copy when starting over again. At that moment, I felt like one of the most important and revolutionary books of the late-twentieth century had been published, then translated, and yet remained much too unknown. No doubt, I still feel that way over a decade later. Today, after all of those theorists of difference in France - Levinas, Derrida, Lyotard, Irigaray, others - have made their splash and changed so much of how we think about subjectivity, time, history, ethics, politics, difference, and so on, Glissant has not yet had his hearing in philosophy. Even as he continues to redefine so much in francophone studies and postcolonial theory.

Poetics of Relation begins with some of the most moving, provocative, and genuinely beautiful pages to be found on the meaning of traumatic experience, survival, creation, and the drama of making meaning after catastrophe. Across those opening pages, we see Glissant formulate the impossible: a theoretical and poetic vocabulary for the experience of the Middle Passage, arrival in the Americas, survival and creation in the Plantation machine, and the slow resistance to, then distance from, 
colonialism. It is a vocabulary that, as it is developed in critical dialogue with an eclectic and wholly unexpected cluster of thinkers (from Victor Segalen to William Faulkner to Albert Einstein to Aimé Césaire to Kamau Brathwaite), grounds the meaning and future of composite, creolized culture. A culture that, in Glissant's formulation, begins with a three-fold sense of the abyss. The abyss of leaving Africa in the belly of the ship. The abyss of the Middle Passage - which Glissant describes as the womb of the Caribbean - that names both the sadness of memory and history and the open horizon of the future. And then the abyss that describes arrival and disorientation. In these three senses of the abyss, Glissant describes how traumatic experience begins or gives birth to the New World. That is, there is no New World without the catastrophe of the genocide of indigenous peoples and the repopulation of the islands through forced migration, enslavement, and political subjugation after emancipation. There is just so much loss. The very word "Americas" bears this pain, which takes on a very particular character in Glissant's treatment of the Caribbean context. And yet, of course, for all of the pain of the past, the New World is not simply the story of terrible suffering. It is also, and foremost for Glissant, a shared experience that makes a people. It is worth quoting him in full on this womb abyss that scatters, then forms a new people. Glissant writes:

Just as the first uprooting was not marked by any defiance, in the same way the prescience and actual experience of Relation have nothing to do with vanity. Peoples who have been to the abyss do not brag of being chosen. They do not believe they are giving birth to any modern force. They live Relation and clear the way for it, to the extent that the oblivion of the abyss comes to them and that, consequently, their memory intensifies. ${ }^{1}$

Memory of the abyss informs - even intensifies - the imaginary of a new people and a wholly new sense of creolized language, culture, and space.

Following immediately from this passage, Glissant turns his address to the ghost: the traumatic memorial figure of the sea for Africans in the Americas, that collective we sometimes too casually call "the diaspora." Glissant's diaspora, which is the diaspora of a people born from the abyss, is unrooted and structured by the unknown (l'inconnu). A diaspora without atavism. He writes:

For though this experience made you, original victim floating toward the sea's abysses, an exception, it became something shared and made us, the descendants, one people among others. Peoples do not live on exception. Relation is not made up of things that are foreign but of shared knowledge. This experience of the abyss can no be said to be the best element of exchange.

For us, and without exception, and no matter how much distance we may keep, the abyss is also a projection of and a 
perspective into the unknown. Beyond its chasm we gamble on the unknown. We take sides in this game of the world. We hail a renewed Indies; we are for it. And for this Relation made of storms and profound moments of peace in which we may honor our boats. $^{2}$

With these words, Glissant initiates a theory of poetics that, from the outset, functions as a sort of a memory project. Not a melancholic project. Not a project of mourning. Instead, this very different remembrance is figured by Glissant as the shoreline - that which lies as the border of the sea-abyss and its traumatic memory, that which begins another trauma and another imaginary in the composite cultural formation of the archipelago, and so a figure of pain but also human beauty. This figure and all of its conceptual weight and thickness simply expresses that peculiar experience: standing at the Caribbean shoreline and saying the impossible, that, at one and the same time, "this is the unspeakable sadness of history" and "this is the most beautiful place in the world." Glissant's great gift to us is a lifetime of meditation on this very simultaneity, drawing out so many of its metaphysical, epistemological, ethical, and aesthetic meanings in multiple registers. The gift: how to say yes to ghosts and hauntings, and so how to welcome the memory of terror because it is the constant, if often mute or muted, companion to the excessiveness and profundity of creolized life.

With the figure of the shoreline, Glissant begins where the Caribbean and the Africana New World generally begin: arrival after the Middle Passage. Life after arrival is the life of the Plantation, a machine of violence and exploitation, of course, but also a mixed site of languages, beliefs, practices, values, and expressions that, in the end, gives birth to what Glissant - in a creolization of Deleuze and Guattari - calls rhizomatic identity. Multiple roots, none generative of the whole, but all implicated in the painfully won, always beautiful chaos of composite cultural life. In Poetics of Relation, Glissant writes:

Just how were our memory and our time buffeted by the Plantation? Within the space apart that it comprised, the always multilingual and frequently multiracial tangle created inextricable knots within the web of filiations, thereby breaking the clear, linear order to which Western thought had imparted such brilliance. ${ }^{3}$

The brilliance of Western thought is set in the linear order, an order that promises roots because it is linear (a line begins somewhere) and promises progress, filiation, folded and folding temporality, secured borders of epistemological, ontological, and aesthetic space, and so, in the end, all kinds of continuity across any and all difference. To be sure, the West has had its breaks with this linearity; one need only think of Walter Benjamin's rightly famous claim in "Theses on Philosophy of History" that the idea of progress is really nothing more than a pile of wreckage. A solid bit of twentieth 
century French existentialism and post-structuralism, along with the early Frankfurt school, has been dedicated to exploring the memory of catastrophe opened up by Benjamin's query and others like it. Still, no matter the ruptures and fissures in the West at moments like these, there is always an appeal to continuity; mourning, after all, presupposes a prior unity, a sort of ontological atavism, toward which the sad gaze of historical thinking is turned. For that reason, and on that basis, so much of the twentieth century in European philosophy and cultural theory has been a mourning project. When we read Glissant, loss and painful memory is foremost - we begin with the abyss(es) - but another temporality becomes possible outside the mourning and repair models of traumatic memory. The traumatic memory of the Plantation is just that new temporality: tangled, mixed, often violent, yet always, in becoming a culture, generative of complex forms of expression and life. Creole and creolizing life.

With this opening motif, Poetics of Relation rewrites he entire epistemology, metaphysics, and aesthetics of the New World. The scope of the project, begun three and a half decades prior in Soleil de la conscience and continued in L'intention poétique and Discours antillais, is enormous, but Glissant's work, for all of its paradigm shifting Chaos and rewriting of the meaning of global cultural contact, exhibits impressive and unique humility. Glissant generates a new conceptual language. In that sense, he is the author of a paradigm shift. Yet the shift exceeds anything Glissant might say about it; his rhetoric is inquisitive, searching, and questioning. His language in Poetics of Relation, just like the ideas at stake there, is fluid, open, and guided, in principle, by the chaotic revision implied by the gerund form creolizing. In a certain sense, his is the sort of humility we might imagine coming from the early Fanon, whose closing line to Black Skin, White Masks asks that he always be a question. The inwardly directed existential openness of Fanon's closing line becomes, across Glissant's work, a questioning openness to global and globalizing points of contact and modes of expression that, while guided by an ethical respect for opacity, move according to the fractal geometry of intellectual exchange. Opacity - the right to reserve and withhold what cannot be commonly known - is crucial for Glissant's account of creolizing culture and the ongoing ethical argument for the absolute value of each of the world's languages, but there is never hegemony or authority in opaque cultural forms. There is, rather, always the openness to contact and the fragility of cultural meaning mixing. A fine risk to take, for sure. The rhizome, then, is not just the being of the Caribbean as a place of new people. The rhizome must be grasped in its verbal sense as well. Glissant's work rhizomes just as it tracks the rhizoming of meaning in toutmonde. As Glissant writes:

I am doing the same thing in the way I say we - organizing this work around it. Is this some community we rhizomed into fragile 
connection to a place? Or a total we involved in the activity of the planet? Or an idea we drawn in the swirls of a poetics? ${ }^{4}$

After the abyss, after so much loss, and in the morass of so much painful memory, there is the beautiful shoreline and the imagined world brought into being. For Glissant, that bringing into being is never animated by a distant light or some other such god. Rather, it is rhizomed, made out of fragments, creating a precarious we and fragile connection to place. Fragility asks a lot of us. It asks important political and ethical questions, leading to the imperative to respect the right to opacity. It also asks for what Walcott, in his Nobel Prize speech, ${ }^{5}$ calls the "love" that assembles fragments and creates the new out of a painful and difficult past. A poetics of Relation.

In close, I want to end with Glissant's own words: the final verse from his massive reimagination of the Americas entitled Les Indes (1956). The poem begins with conquest and the slave trade, moves through the Plantation and the colonial relation, and ends exactly where it all began - at the shoreline. Across Les Indes, Glissant puts his signature complexity as a thinker into dense, emotionally tangled verse, evoking Columbus and his violence, the suffering and survival of the diaspora, revolution in the name of Toussaint, love and marriage, and so much more. All of those evocations resonate the ambivalences and double-significations of what he later comes to call Relation. Out of pain, so much is possible. Even in the possible, even in the future accomplished as creolized and creolizing space and time, there is remembrance. He writes:

Ô course! Ces forêts, ces soleils vierges, ces écumes

Font une seule et même floraison! Nos Indes sont,

Par delà toute rage et toute acclamation sur le rivage délaissées

L'aurore, la clarté courant la vague désormais

Son Soleil, de splendeur, mystère accoutumé, ô nef,

L'âpre douceur de l'horizon en la rumeur du flot,

Et l'éternelle fixation des jours et des sanglots. ${ }^{6}$ 
1 Édouard Glissant, Poétique de la relation. (Paris: Gallimard, 1990), 20; Poetics of Relation, trs. Betsy Wing. (Ann Arbor: University of Michigan Press, 1997), 8.

${ }^{2}$ Glissant, Poétique de la relation, 20-21/8-9.

${ }^{3}$ Glissant, Poétique de la relation, 86/71.

${ }^{4}$ Glissant, Poétique de la Relation, 222/206.

${ }^{5}$ Derek Walcott, “The Antilles: Fragments of Epic Memory," in What the Twilight Says. (New York: Farrar, Straus, Giroux, 1999), 69.

${ }^{6}$ Édouard Glissant, “Les Indes,” in Poèmes complets. (Paris: Gallimard, 1994), 165.

In créole translation:

A ! kous !

Sé gran-bwa-tala, sé soley nef-tala, sé tjim-tala,

Ka fè an sel ek menm florézon!

Lézenn nou sé,

$\mathrm{Pa}$ anlè tout konba ek tout aklamaison anlè

bòdaj-lanmè oublié-a,

Bonmaten,

Limiè ki ka kouri anlè tjim atjolman,

Soley-li, adan wotè'y, mistè akoutimé,

A ! nef ! Dousè anmè lorizon anlè rimè flo,

Ek éternel fiksaison jou ek sanglo.

(“Lézenn,” trs. Rodolf Etienne, in Les Indes, Lézenn (Édition bilingue français/créole). [Éditions du Rocher/Le Serpent à Plumes, 2005], 171.)

In first English translation:

O course! These forests, these virgin suns, these foams

Are one and the same flowering! Our Indies are

Beyond all rage and all acclamation abandoned on the shore,

The dawn, the light henceforth chasing the wave

Its Sun, of splendour, usual mystery, O vessel,

The harsh gentleness of the horizon in the water's murmur,

And the eternal fixation of days and of weeping.

(“The Indes,” trs. Dominique O'Neill, in The Indes, Les Indes (Bilingual Edition). [Toronto: Éditions du GREF, 1992], 99.) 


\section{In second English translation:}

O journey! These forests, these virgin suns, these waves

Are one and the same efflorescence! Our Indes are

Beyond all rage and acclamation, these are left behind on the shore,

Dawn, radiance sailing the wave henceforth

Its Sun, of splendor, inured mystery, O ship,

Rugged calm of the horizon amid an uproar of currents,

And the eternal fixity of days and tears.

("The Indes," trs. Jeff Humphries with Melissa Manolas, in The Collected Poems of Édouard Glissant. [Minneapolis: University of Minnesota Press, 2005], 100. 